\title{
Loss of Friction Force Due to High Temperature Effect on A325 Bolts with Proof Load on Steel Bridge
}

\author{
Noval Hasan ${ }^{1, *}$ Riawan Gunadi $^{2}$ Moeljono $^{2}$ Fisca Igustiany ${ }^{2}$ \\ ${ }^{I}$ Student of Master Applied Infrastructure Engineering, Politeknik Negeri Bandung, Jawa Barat, Indonesia \\ ${ }^{2}$ Departmen of Civil Engineering, Politeknik Negeri Bandung, Jawa Barat, Indonesia \\ *Corresponding author. E-mail: noval.hasan.mtri18@polban.ac.id
}

\begin{abstract}
Steel construction joints are critical parts and determine the overall strength of the structure, one of which is when subjected to high temperatures. The performance of bolt connections on steel bridges is very important to be considered in bridge design. The research results on the performance of the steel beams need to be supplemented with the performance testing of the post-fire girder bridge bolt connection. Six steel beams with shear-type high strength bolt connection in the middle of the span were tested under monotonic vertical point load located at the beam mid-span. Three specimens use proof load in their connections (Proof Load Specimens), while the others use a snug tight bolt (Snug Tight Specimens). As control specimens, two specimens (SS020 Proof Load and SS020 Snug Tight) were tested structurally without combustion. Two specimens (SS700 Proof Load and SS700 Snug Tight) were tested structurally after being burned under $700^{\circ} \mathrm{C}$. The other two specimens (SS900 Proof Load and SS900 Snug Tight) were tested structurally after being burned under $900^{\circ} \mathrm{C}$. The experimental results combined with reviewed using a scanning electron microscope (SEM) to determine changes in the microstructure due to the temperature given to charged objects. The best post-burn connection in the field is bolted connection with proof load tightening because it can increase strength up to $11 \%$. Even after being burned, the proof load joint still proves the highest performance than the joint without being subjected to initial tensile forces.
\end{abstract}

Keywords: Bolt Connection, steel bridge, post-fire, friction, elongation.

\section{INTRODUCTION}

A fire event has the potential to cause collapse or serious damage to steel bridges with reinforced concrete floors. In case of minor damage, the effect of fire cannot be calculated. In this case, engineers must review performance and behavior to decide whether the bridge can be re-operated or should be rebuilt [1]. Publications and research on the resistance of bridge structural elements to fire are still very limited. When compared with steel building structures, the behavior of steel girders on bridges against fire is very different from steel beams on buildings related to fire properties, structural geometry, and cross-sectional characteristics. Therefore the research results from buildings cannot be applied directly to bridge girders [2]. Bridge fires have occurred in Indonesia, at the Kali Krasak bridge in Central Java and the Ampera bridge in Palembang. Kali Krasak Bridge collapsed due to a fire accident in a fuel oil truck [1]. Many research results on the post-burn structure prove that the structure's performance drops significantly under the influence of high temperature. One of them is the burn test on the beam model IWF250-125-6-9 with a distance of 3 meters, which shows that the decrease in the performance of the structure is influenced by three factors, namely temperature, load during combustion, and combustion time. The test results show that the beam model with a center load of $38 \mathrm{kN}$ in the center of the span can withstand temperatures of $550^{\circ} \mathrm{C}$ for 120 minutes without significant reduction with a deflection of about $10 \mathrm{~mm}$ and is much larger than a similar specimen burning at the same temperature with a load of $19 \mathrm{kN}$. Burning at a target temperature of $900^{\circ} \mathrm{C}$ for approximately 20 minutes showed that specimens with a load of $19 \mathrm{kN}$ experienced a very large deflection with a deflection of up to $150 \mathrm{~mm}$, while specimens with a load of $38 \mathrm{kN}$ collapsed due to lateral flexural [3]. The above results are consistent with the test results numerical (Gunadi, 2016), which proves that at a temperature of $600^{\circ} \mathrm{C}$, the 
beam's stiffness and flexural capacity has very significantly decreased. At this temperature, the maximum stress that can be achieved is far below the yield stress of the material [4]. Another study is that the steel profile bolt joints that are burned and subjected to a flexural test with Universal Testing Machine (UTM) have been shown to reduce the plate friction force by $12 \%$, thereby reducing the post-fire friction performance [5].

Experimental research has been carried out on the performance of post-fire steel girder beams. However, research on the post-fire performance of steel structure joints is still limited. Therefore, research on the performance of steel joints is needed to support the post-fire structural steel performance results and the handling of reinforcement performance. [6]

\subsection{Research Limitations}

To obtain the research results in this paper, the method used is experimental testing with combustion and flexural tests on the bolt connection specimen profile to obtain the load and displacement relationship by observing the reduced friction force due to the extension of the bolt from post-fire events. Limitation of test equipment on high-strength bolts was carried out by reviewing changes in size and chemical degradation properties using Scanning Electron Microscopic (SEM) as reinforcement from the results of experimental tests.

\subsection{Our Contribution}

The purpose of this paper is to obtain an effort to prevent a decrease in the performance of post-fire bolt connections by reviewing the experimental test results and seeing changes in the physical microstructure of steel bolts on the IWF test object connection, as for what needs to be achieved to determine the magnitude of the load transferred from each variable to the joint performance, namely the frictional force lost after a fire. The benefits of this research are to provide information and considerations in installing joints in the field as a fire prevention measure in steel bridge connection structures and provide information about the frictional forces of post-fire joints and provide input for bridge elements planning regulations in Indonesia.

\section{BACKGROUND}

Experimental investigations have shown that the basic behavior and strength of steel bars are highly dependent on the surface temperature of the steel [7]. The collapse of steel profiles due to fire at a center distance is faster than at the edge of reach [8]. The decrease in strength of steel-concrete composite beams is influenced by temperature and burning time, whereas if the temperature increases, the steel-concrete composite beam will experience a decrease in the ductility factor which causes the beam's ability to accept loads also becomes weak [9]. Bolts that are given a proving load are still in the elastic stress range, so the elongation bolts are relatively small. If the initial tensile strength exceeds the proof load, the bolt tension that occurs is in a plastic condition and is close to $90 \%$ of the bolt's tensile strength. Such stressful conditions are considered very dangerous [10]. At this temperature, the maximum stress that can be achieved is far below the yield stress of the material [11].

Testing the pretension of the A325 type of slip critical bolt used variations of pretension $90 \mathrm{~Tb}, 100 \mathrm{~Tb}$, and $110 \mathrm{~Tb}$ for torque rotations of $2 / 3,3 / 6$, and $4 / 6$ for manual pretension tools, respectively. Tensile tests were carried out with variations and various locking methods. The results showed that the tensile strength values in both methods, namely the torque wrench and manual (turn of nut) locking methods were the same, and the results of the failure behavior were in the shear bolt and the plate changes to an oval shape [12].

However, there is very limited research on the performance of post-fire steel structural joints. Therefore, research on the performance of steel structure trays needs to be studied to support the results of post-fire steel beam performance and alternative handling performance. Experimental testing and SEM showed the behavior and performance of the friction force on the bridge bolt connection post-fire. [6]

\section{RESEARCH METHODS}

The outline of the research includes three types of tests, namely the specimen burning test to determine changes in steel characteristics, post-combustion steel joint structure test to obtain a performance comparison at the joint, and the Scanning electron microscopic (SEM) test to support experimental results on bolt testing which shows a degradation of the elements. The steel beam specimens tested consisted of six steel beam specimens with shear bolt connections (SS type). The research steps to be carried out are as follows:

1) Burning of two steel beam specimens at a temperature of $700^{\circ} \mathrm{C}(\mathrm{SS} / 700)$, with one specimen with Snug-tight bond and Proof load.

2) Burning of two specimens of steel beams at a temperature of $900^{\circ} \mathrm{C}$ (SS/900), with one specimen with Snug-tight bond and Proof load.

3) Structural test by UTM on two unburned control specimens (SS/020)

4) Structural test with UTM on four post-combustion specimens

5) Evaluating the decline in the performance of the specimen by using the test results on the control specimen (SS/020)

6) Obtaining microstructure visual support data from test results using Microscopic Scanning Electron (SEM)

Structural tests were carried out on specimens in the form of a bridge girder model with a reduced scale (Sub scale). The dimensions of the girder specimens are as shown in Figure 1 and Table 1. 


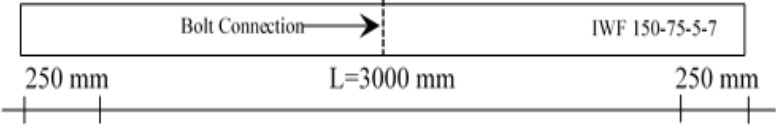

Figure 1 Specimen Illustration

Table 1. Dimension of IWF Specimen

\begin{tabular}{|c|c|c|c|c|}
\hline $\mathrm{H}(\mathrm{mm})$ & $\mathrm{B}(\mathrm{mm})$ & $\mathrm{t}_{\mathrm{w}}(\mathrm{mm})$ & $\mathrm{t}_{\mathrm{f}}(\mathrm{mm})$ & $\mathrm{L}(\mathrm{mm})$ \\
\hline 150 & 75 & 5 & 7 & 35000 \\
\hline
\end{tabular}

The type of bolt used is a high-quality bolt type specified by ASTM, namely A325 with a bolt diameter of $1 / 2$ inch with a bolt length of $5 \mathrm{~cm}$. A325 bolts are made of medium carbon steel with yield strengths from 560 to $630 \mathrm{MPa}$. In the implementation of fastening bolts using the turn-of-nut tightening method. The implementation of bolt tightening used the turn-of-nut method by using two different bonding variables, namely proof load and snug tight. In the proof load bond, for providing proof load strength up to $70 \%$ of the maximum yield strength, it was carried out using a torque wrench to measure the strength of the plan. In a snug tight bond, a sufficient number of bolts were used in a tight fit condition to ensure that all the parts connected were in good contact. A snug tight is defined as the tightness produced by a shock nut wrench or by full human effort using an open-ended spud-wrench. The details of the beam specimen connection plans are as shown in Figure 2 for each beam specimen with shear connection (SS). The connection details are designed to withstand the same shear load due to the gravity load on the beam. The distance between the axles of the bolts to the ends of the plates $(\mathrm{S}=30 \mathrm{~mm})$, the distance between the bolts $(\mathrm{U}=30 \mathrm{~mm}, \mathrm{U} 2=40 \mathrm{~mm})$.

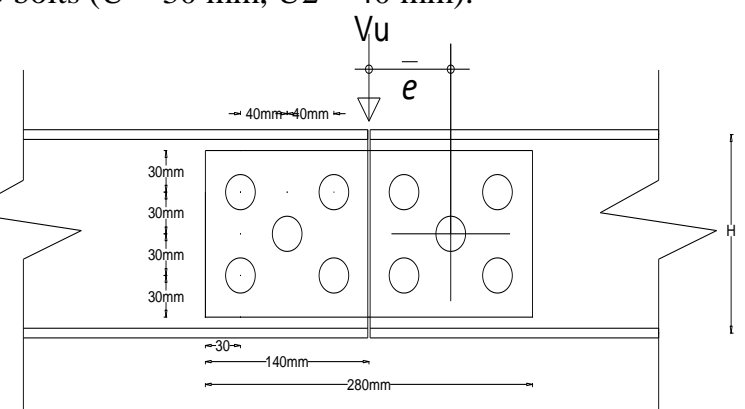

Figure 2 Bolt Connection Plan Details

The burn test was carried out at the Science Laboratory of the Housing Research and Development Center of the Ministry of PUPR, using a burning furnace as shown in Figure 3. Burning on all four specimens and given a high temperature is shown in table 2.

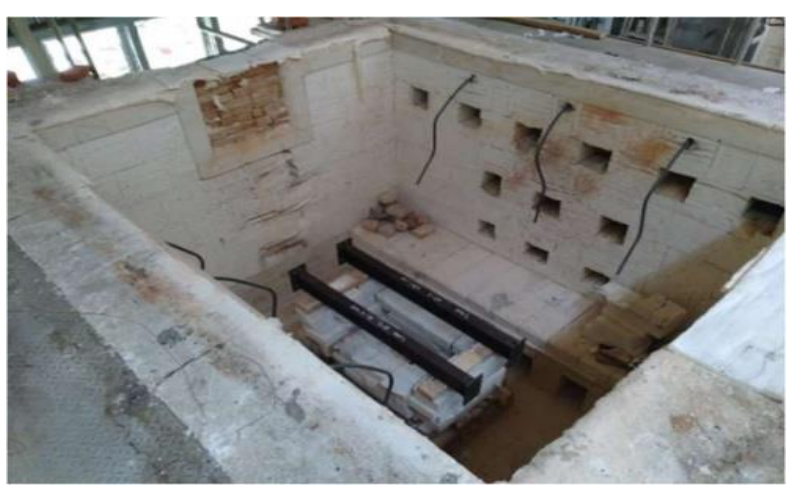

Figure 3 Burning Furnace

Table 2. Specimen type and burn

\begin{tabular}{|c|c|c|}
\multirow{2}{*}{ SPECIMEN } & \multicolumn{2}{|c|}{ BURN TARGET } \\
\cline { 2 - 3 } & $\begin{array}{c}\text { TEMPERA- } \\
\text { TURE }\left({ }^{\circ} \mathrm{C}\right)\end{array}$ & $\begin{array}{c}\text { DURATION } \\
\text { (minute) }\end{array}$ \\
\hline SS/020 (Snug-tight) & - & - \\
\hline SS/020 (Proof load) & - & - \\
\hline SS/900 (Snug-tight) & 700 & 120 \\
\hline SS/900 (Proof load) & 700 & 120 \\
\hline SS/700 (Snug-tight) & 900 & 120 \\
\hline SS/700 (Proof load) & 900 & 120 \\
\hline
\end{tabular}

In the flexural test, the object studied was the shear joint in the middle of the span. The illustration of monotonic loading is shown in Figure 4, with the loading pattern on the specimen carried out monotonically based on ASTM C293/293 C M-16 with a maximum loading capacity of $\mathrm{P}=50$ tons. The loading test, in this case, is 8 tons.

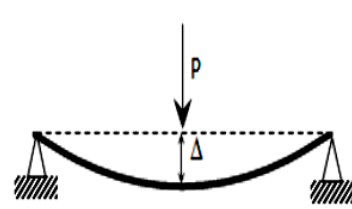

(a)

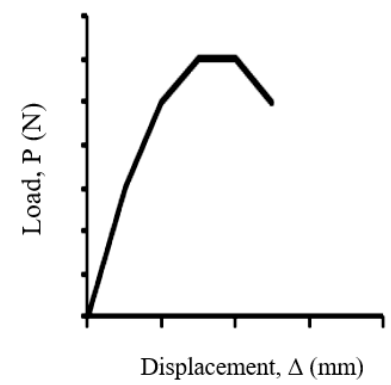

Figure 4 Displacement controlled monotonic loading scheme (Gunadi et al., 2017)

The loading test is carried out using Universal Testing on the Machine shown in Figure 5. 


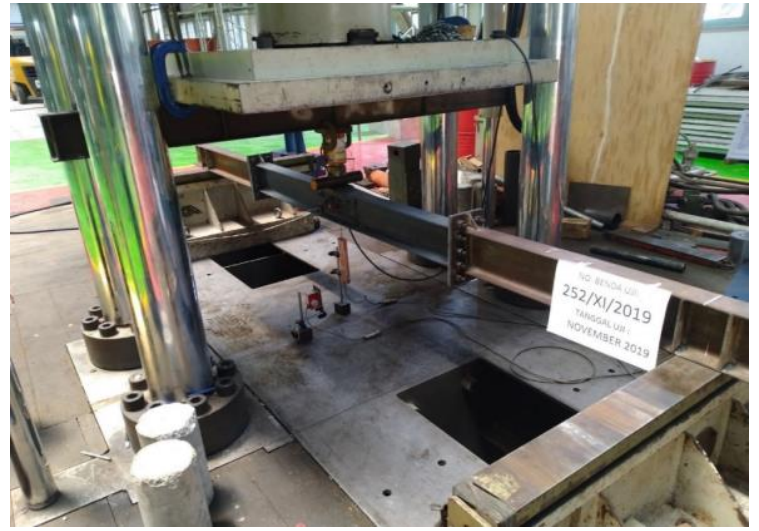

Figure 5 Universal Testing Machine (UTM) for Load Test

Scanning Electron Microscopic (SEM) testing functions as a supporter of experimental results on bolt testing. Things reviewed are in the form of elongation of the bolt, diameter of the bolt, and the degradation of the steel content in the bolt. SEM was carried out with a magnification scale of up to $2000 x$, aiming to obtain sufficient topography on the surface and obtain the value of the steel component content with Energy Dispersive X-Ray Spectroscopy EDS. The illustration at the time of testing is shown in Figure 6.

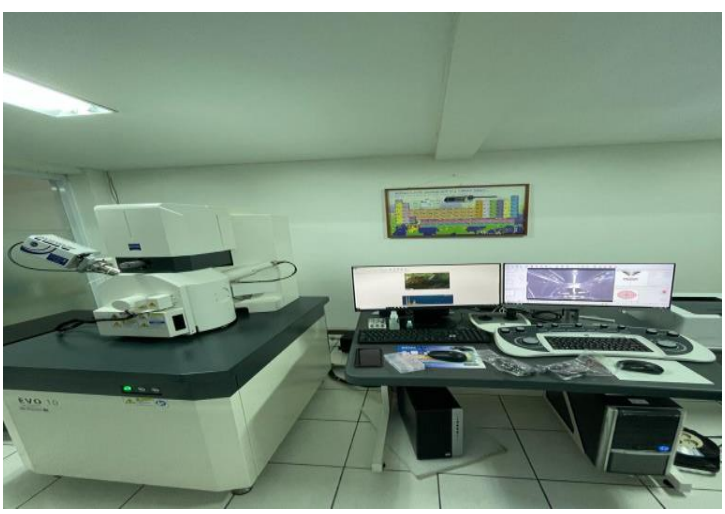

Figure 6 Scanning Electron Microscope (SEM) Instrument

The bolt test object was formed in small pieces such as a disc by taking a sample in the center of the A325 bolt plane to be inserted into the SEM machine, as shown in Figure 7.

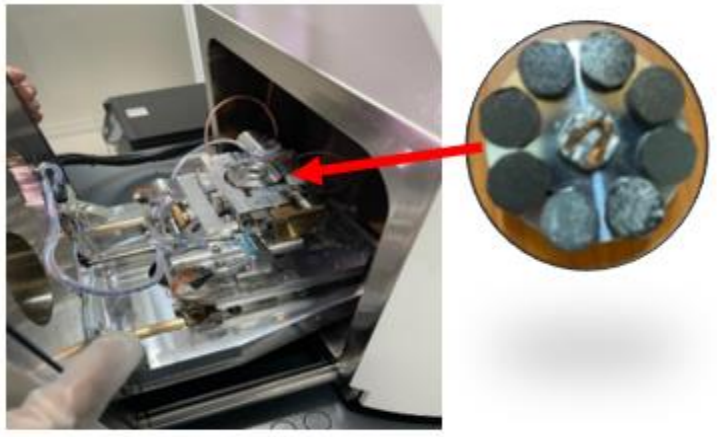

Figure 7 Illustration of Making and Laying SEM Test Objects

\section{RESEARCH AND DISCUSSION}

The test specimens that had been burned were then cooled in the furnace for up to 2 days by the slow cooling method or by using the room temperature of the furnace itself. This method was carried out to avoid direct cooling which results in changes in the physical properties of the steel material, such as using an analytical method that affects the hardness of the steel. The following in Figure 8 shows the color change due to combustion temperature.

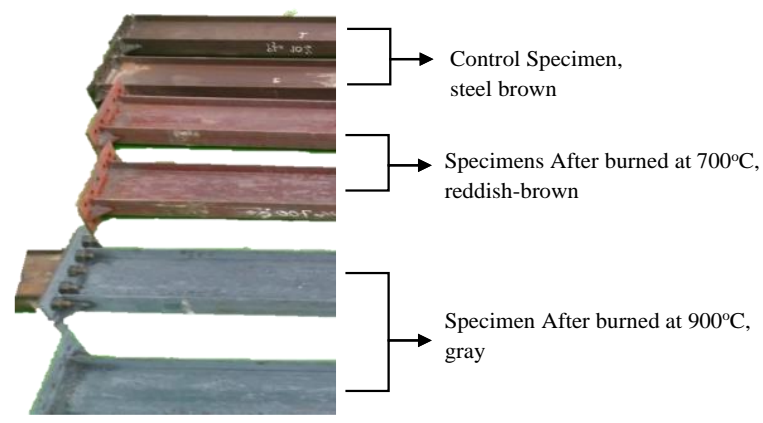

Figure 8 Universal Testing Machine (UTM) for Flexural Test

After burning and cooling, a flexural test was carried out with the results shown in Figure 9.

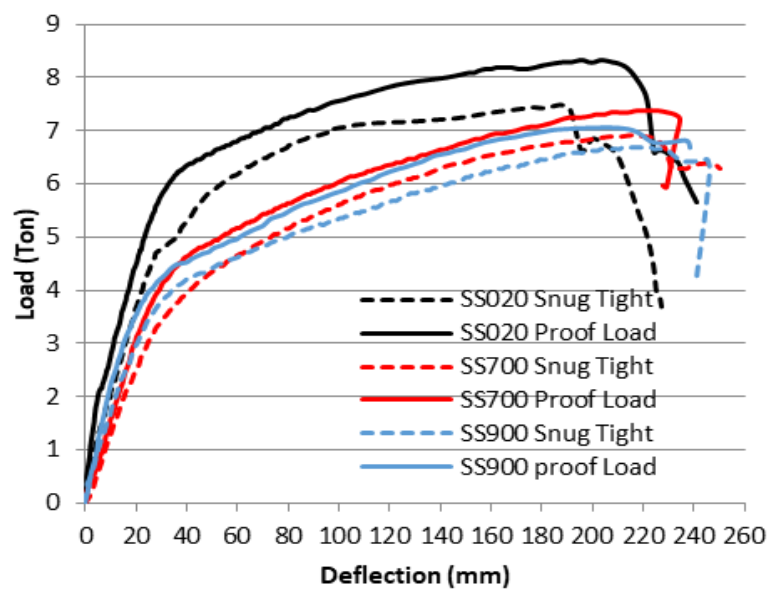

Figure 9 Load-Deflection Relationship Flexural Test Results

The graph above shows the load-displacement curve of the flexural test of each specimen.

1. The snug-tight bolt bond control specimen experienced a deformation point of $187 \mathrm{~mm}$ at a load of 7.6 Tons.

2. Control specimens with proof load bonds given an initial tensile (proof load) resulted in a critical slip on the plate. This resulted in additional strength/transfer strength in the performance of the IWF profile so that it could withstand loads of up to 8.3 ton with a deflection of $250 \mathrm{~mm}$. 
3. Specimens with snug-tight bonds after being given a temperature of $700^{\circ} \mathrm{C}$ experienced a decrease in performance from the load resistance and deflection that occurred. Specimens with snug-tight bolts experienced a yielding point at a load of 7.09 tons with a resulting deflection of $228.5 \mathrm{~mm}$.

4. Specimens with proof load bonds that were given an initial tensile (proof load) which resulted in critical shear on the plate after being burned at a temperature of $700^{\circ} \mathrm{C}$ experienced a deflection of $226 \mathrm{~mm}$ with a load of 7.36 tons.

5. Specimens with snug-tight bonds after being burned at a temperature of $900^{\circ} \mathrm{C}$ experienced a decrease in performance from the load resistance and deflection that occurred. Specimens with snug-tight bolts experienced a yielding point at a load of 6.69 tons with a resulting deflection of $223.75 \mathrm{~mm}$.

6. Specimens with proof load bonds that were given an initial tensile (proof load) which resulted in a critical shear on the plate after being burned at a temperature of $900^{\circ} \mathrm{C}$ experienced a deflection of $210.35 \mathrm{~mm}$ with a load of 7.06 Tons. The performance of the two types of connection, namely the SS/900/Snug-tight specimen and the SS/900/proof-load specimen, is almost close to the load-displacement relationship, and there is a reduction in the shear force between the plates due to the effect of high temperatures exerted on the proof-load bond specimen.

From the recapitulation of the flexural test data in Figure 9, it is illustrated that the bolt connection with the provision of an initial tensile force (proof-load) has a major influence on the performance of the specimen. The SS/020/PL specimen as a control proved the best peak performance from other specimens. This is due to the influence of the frictional force exerted by the bolt's initial tensile force, which results in the critical slip between the plates. Then after being burned at a temperature of $700^{\circ} \mathrm{C}$ and up to a temperature of $900^{\circ} \mathrm{C}$, the performance of the specimen decreased in the deformation and load that it could withstand when the flexural test was carried out. This is assumed because the effect of the friction force due to the initial tensile force on the bolt (proof load) is lost when it is burned at high temperature with the critical slip condition not returning to its original state. The burnt test object is shown in Figure 10.

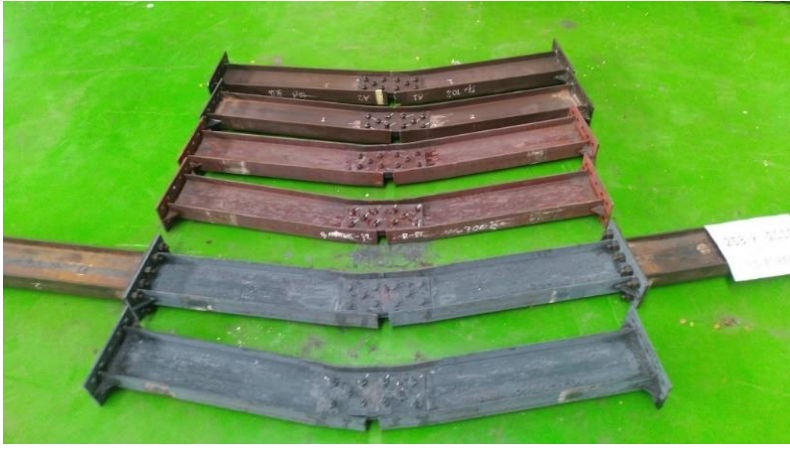

Figure 10 Specimens that have been tested for flexural

Then the experimental results were supported by using SEM to obtain steel degradation in the bolts that were given initial stress (proof load) and given a high temperature so that the bolt elongation and bolt diameter was reduced. Before conducting the SEM test on the test object, first, an observation of the diameter and length of the bolt was carried out using a digital caliper with a $5 \mathrm{~mm} \mathrm{A325}$ bolt length and $12.7 \mathrm{~mm}$ bolt diameter. Bolts on specimens that have been burned at a temperature of $900^{\circ} \mathrm{C}$, were measured using a digital caliper with a bolt length of $5.17 \mathrm{~mm}$ and a bolt diameter of $11.8 \mathrm{~mm}$. The measurement of the length of the A325 bolt with a proof load bond of $900^{\circ} \mathrm{C}$ is shown in Figure 11, and the measurement of the diameter of the bolt is shown in Figure 12.

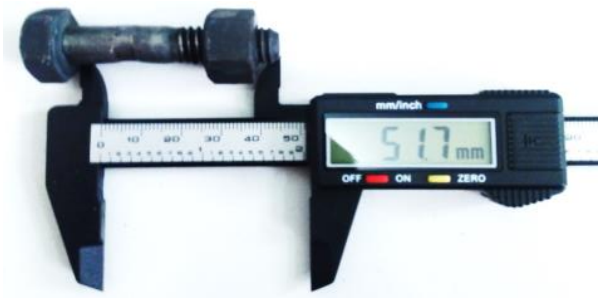

Figure 11 Bolt Elongation Measurements

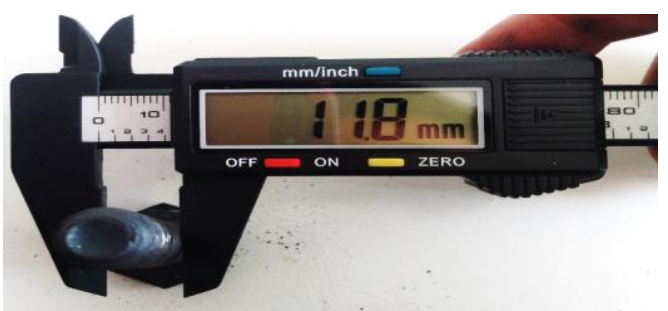

Figure 12 Bolt Diameter Reduction Measurements

The results of SEM with element decomposition using Energy Dispersive X-Ray Spectroscopy EDS on a snug tight bolt control specimen are shown in Figure 13, and on a proof load specimen burned at a temperature of $900^{\circ} \mathrm{C}$ is shown in Figure 14, where the components in red are elements of steel $(\mathrm{Fe})$, blue are elements of silica (Si). 

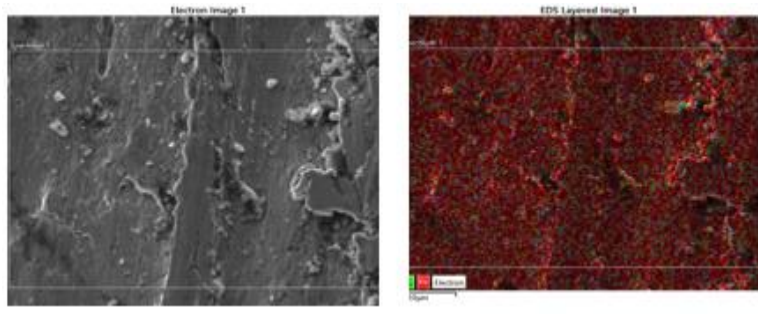

Figure 13 Energy Dispersive X-Ray Spectroscopy layer 2000x magnification on A325 control bolt
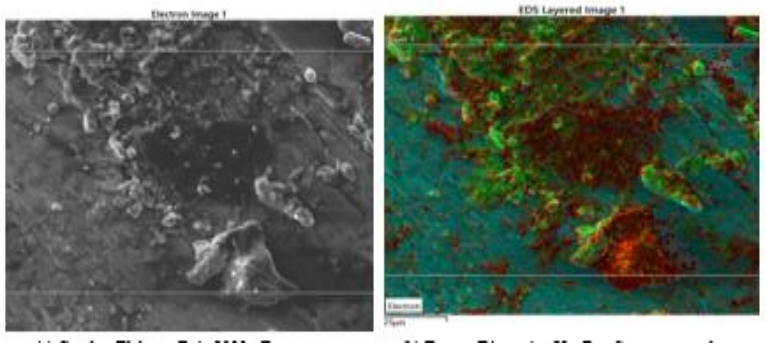

Figure 14 Energy Dispersive X-Ray Spectroscopy layer (EDS layer) 2000x on A325 bolts after being given a temperature of $900^{\circ} \mathrm{C}$

Figure 15 shows a graph of the chemical elements on the steel surface that have been analyzed by EDS showing the ratio of the percentage of degradation. The composition of the degradation reduction of steel $(\mathrm{Fe})$ is shown in Figure 16. Table 3 shows the SEM results of the degradation content of the bolts.

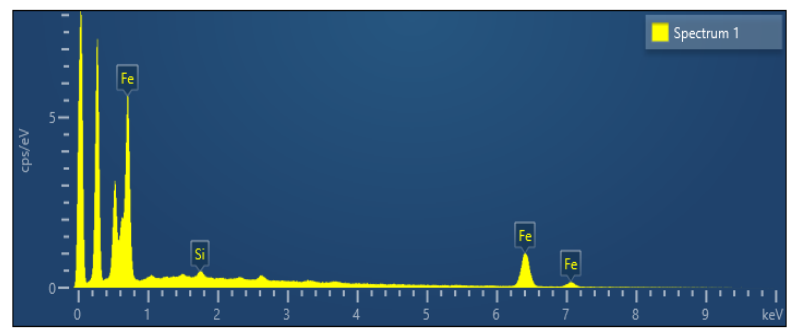

Figure 15 The results of the EDS search for the A325 bolt after being given a temperature of $900^{\circ} \mathrm{C}$

Table 3. The results of the search for steel content from SEM on A325 bolts after being given a temperature of $900^{\circ} \mathrm{C}$

\begin{tabular}{|c|c|c|c|c|}
\hline \multicolumn{5}{|c|}{ Spectrum 1} \\
\hline Element & $\begin{array}{l}\text { Line } \\
\text { Type }\end{array}$ & $\begin{array}{c}\text { Weight } \\
(\%)\end{array}$ & $\begin{array}{c}\text { Weight } \\
(\%) \\
\text { Sigma }\end{array}$ & $\begin{array}{c}\text { Atomic } \\
(\%)\end{array}$ \\
\hline $\mathrm{O}$ & $\mathrm{K}$ series & 10.70 & 0.15 & 29.33 \\
\hline $\mathrm{Fe}$ & L series & 88.59 & 0.17 & 69.56 \\
\hline $\mathrm{Si}$ & K series & 0.71 & 0.06 & 1.12 \\
\hline Total & & 100.00 & & 100.00 \\
\hline
\end{tabular}

The recapitulation of the SEM results of all tested bolts is summarized in table 4.
Table 4. Recapitulation of bolt Measurements and SEM results

\begin{tabular}{|l|c|c|c|c|c|c|}
\hline $\begin{array}{l}\text { Bolt } \\
\text { Specimen }\end{array}$ & 1 & 2 & 3 & 4 & 5 & 6 \\
\hline $\begin{array}{l}\text { Temperature } \\
\left({ }^{\circ} \mathrm{C}\right)\end{array}$ & 020 & 020 & 700 & 700 & 900 & 900 \\
\hline Bolt & $\begin{array}{c}\text { Proof } \\
\text { load }\end{array}$ & $\begin{array}{c}\text { Snug } \\
\text { Tight } \\
020\end{array}$ & $\begin{array}{c}\text { Snug } \\
\text { Tight } \\
700\end{array}$ & $\begin{array}{c}\text { Proof } \\
\text { load } \\
700\end{array}$ & $\begin{array}{c}\text { Snug } \\
\text { Tight } \\
900\end{array}$ & $\begin{array}{c}\text { Proof } \\
\text { load } \\
900\end{array}$ \\
\hline Fe \% & 97.85 & 97.95 & 96.19 & 95.62 & 93.39 & 88.29 \\
\hline Si \% & 0.41 & 0.31 & 0.58 & 0.44 & 0.72 & 0.81 \\
\hline Others \% & 1.74 & 1.74 & 3.23 & 3.94 & 5.89 & 10.9 \\
\hline Total \% & 100 & 100 & 100 & 100 & 100 & 100 \\
\hline $\begin{array}{l}\text { bolt length } \\
\text { (mm) }\end{array}$ & 50.0 & 50.0 & 50.8 & 50.2 & 50.6 & 51.7 \\
\hline $\begin{array}{l}\text { Bolt } \\
\text { diameter } \\
(\mathrm{mm})\end{array}$ & 12.7 & 12.7 & 12.6 & 12.5 & 12.5 & 11.8 \\
\hline
\end{tabular}

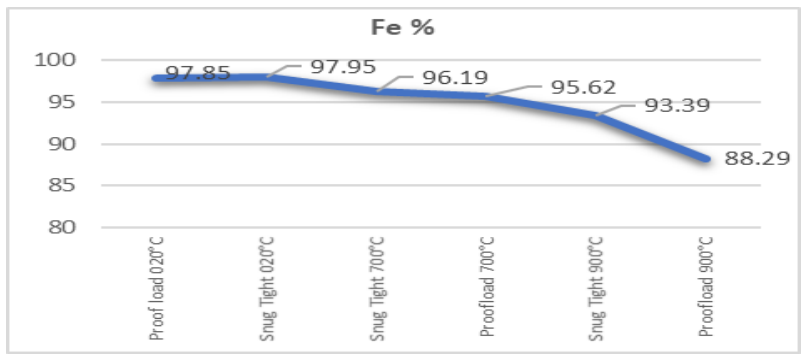

Figure 16 Degradation of Fe Content in A325 Bolts Garp.

The surface of the control steel A325 bolt microstructure with the composition of the Fe content with degradation is close to the ASTM A325-10 material standard of $97.048 \%$. The A325 bolt test object burned to a temperature of $900^{\circ} \mathrm{C}$ proves that the change in the degradation of the $\mathrm{Fe}$ element is not significant. The A325 bolt test object burned to a temperature of $900^{\circ} \mathrm{C}$ proved a significant change in degradation due to a critical temperature of $1000 \mathrm{~K}$ (above $727^{\circ} \mathrm{C}$ ) which has reached the austenite phase, which caused the condition of the alloy steel composition to become nonmagnetic so that the state of the bolt that was tightened in a burnt state stretched and not back to its original state after being burned.

\section{CONCLUSION}

1. Strength in specimens using Proof Load pretensioning can increase strength by up to $11 \%$ compared to fitting tightenings that are not pretensioned. The decrease in performance on specimens of bolted connections with postcombustion Proof Load bonds is still higher than specimens with post-combustion fittings.

2. There is a decrease in capacity to the effect of temperature and initial tensile force on the postcombustion specimen. Proof load specimens after being burned at a temperature of $700^{\circ} \mathrm{C}$ can reduce the strength capacity up to $12 \%$, and after being burned at a temperature of $900{ }^{\circ} \mathrm{C}$ can reduce the 
strength significantly up to $15 \%$. While the specimens without proof load after being given a temperature of $700{ }^{\circ} \mathrm{C}$ and $900{ }^{\circ} \mathrm{C}$, the performance decreased by $5 \%$ to $11 \%$.

3. SEM test proves the difference in the degradation of the two types of connection due to the effect of treatment on $\mathrm{Fe}$; $\mathrm{Si}$; $\mathrm{O}$; bolt diameter; $\mathrm{L}$ bolt of all specimens. The higher the temperature is given to the bolt with proof load tightening, the greater the degradation of the Fe element so that an extension of the bolt occurs due to the initial tensile force applied during the fire which results in the stretching of the bolt not returning to its original state.

4. The best connection in the field is bolted connection with proof load tightening because it can increase strength up to $11 \%$. Even after being burned, the proof load joint still proves the highest performance than the joint without being subjected to initial tensile forces.

\section{ACKNOWLEDGMENT}

This research was supported by Kementerian Pekerjaan Umum dan Perumahan Rakyat Badan Penelitian dan Pengembangan Puslitbang Permukiman Indonesia and thank UPPM Politeknik Negeri Bandung, Civil Engineering Department, for direct testing to complete this research.

\section{REFERENCES}

[1] Sidik, Fajar Fakriyansyah (2018), Peningkatan Kinerja Balok Jembatan Pasca Kebakaran dengan Penambah Fire- Resisstant Coating. Master's Thesis. Politeknik Negeri Bandung. http://digilib.polban.ac.id/gdl.php?mod=browse\&o p=read\&id=jbptppolban-gdl-fajarfikri-9572

[2] Kodur, Venkatesh, Esam Aziz and Mahmud Dwaikat. 2013. Evaluating Fire Resistance of Steel Girders in Bridge. American Society of Civil Engineering(ASCE).

https://doi.org/10.1061/(ASCE)BE.19435592.0000412

[3] Gunadi, R., Mujiman, Moeljono, Igustiany, F. (2017), Kinerja Balok Baja Elemen Jembatan Pasca Kebakaran, Research Report, Politeknik Negeri Bandung. (Report)

[4] Gunadi, Riawan (2016), Analisis Numerik terhadap Kinerja Balok Baja Pada Temperatur Tinggi, Politeknik Negeri Bandung. (Report)

[5] Gunadi, R., Mujiman, Moeljono, Igustiany, F., Hasan, Noval (2020), Bolt Connection Performance Post Fire in Steel Bridge, IOP Conference Series: Materials Science and Engineering. Bandung. https://doi.org/10.1088/1757-899X/830/2/022052
[6] R Gunadi et al 2020. Bolt Connection Performance Post Fire In Steel Bridges. IOP Conf. Ser.: Mater. $\begin{array}{llll}\text { Sci. } & \text { Eng. } & 830 & 022052 .\end{array}$ http://dx.doi.org/10.1088/1757899X/830/2/022052

[7] Choe, Lisa, Anil Agarwal, dan Amit H. Varma. 2016. Steel Column Subjected to Thermal Gradients from Fire Loading: Experimental Evaluation. American Society of Civil Engineering.

https://doi.org/10.1061/(ASCE)ST.1943$\underline{541 X .0001500}$

[8] Imansyah, Maulana Derry, Faris Haqqul Anwar, Sugeng P. Budio, Roland Martin S. 2016. Analisis Keamanan Jembatan Rangka Baja Soekarno-Hatta Malang Ditinjau Dari Aspek Kesehatan, Tegangan Pelat Buhul dan Simulasi Kebakaran. Universitas Brawijaya: Fakultas Teknik, Jurusan Teknik Sipil. http://sipil.studentjournal.ub.ac.id/index.php/jmts/a rticle/view/5

[9] Lilis Indriani, Ahmad Tohir (2016), Kuat Lentur Balok Komposit Baja-Beton Pasca Kebakaran, Universitas Darwan Ali, Kalimantan Tengah. ISSN : 2089-3949. (Unlink/Unpublish)

[10] Rump, J.L. and Fisher, J.W. (1963). Journal of the Structural Division. "Calibration of A325 Bolts". ASCE, 89, ST6 (December 1963). https://www.researchgate.net/publication/2683557 54 Guide to Design_Criteria_for_Bolted_and_Ri veted Joints_Second_Edition (Book)

[11] Salmon, C.G. and Johnson, J.E. (1990). Steel Structure: Design and Behaviour, Third Edition, Harper Collins Publisher, USA. (Book)

[12] Gutama Ardison, Kurniawandy A and Warman Fatra. 2015. Studi Eksperimental Variasi Pretensionsambungan Baut Baja Tipe Slip Critical. Fakultas TeknikUniversitas Riau, Pekanbaru. https://jom.unri.ac.id/index.php/JOMFTEKNIK/art icle/view/6436. 